This document was prepared in conjunction with work accomplished under Contract No.

DE-AC09-76SR00001 with the U.S. Department of Energy.

\title{
DISCLAIMER
}

This report was prepared as an account of work sponsored by an agency of the United States Government. Neither the United States Government nor any agency thereof, nor any of their employees, makes any warranty, express or implied, or assumes any legal liability or responsibility for the accuracy, completeness, or usefulness of any information, apparatus, product or process disclosed, or represents that its use would not infringe privately owned rights. Reference herein to any specific commercial product, process or service by trade name, trademark, manufacturer, or otherwise does not necessarily constitute or imply its endorsement, recommendation, or favoring by the United States Government or any agency

thereof. The views and opinions of authors expressed herein do not necessarily state or reflect those of the United States Government or any agency thereof.

This report has been reproduced directly from the best available copy.

Available for sale to the public, in paper, from: U.S. Department of Commerce, National Technical Information Service, 5285 Port Royal Road, Springfield, VA 22161, phone: (800)

553-6847, fax: (703) 605-6900, email: orders@ntis.fedworld.gov online ordering: http://www.ntis.gov/ordering.htm

Available electronically at http://www.doe.gov/bridge

Available for a processing fee to U.S. Department of Energy and its contractors, in paper, from: U.S. Department of Energy, Office of Scientific and Technical Information, P.O. Box 62, Oak Ridge, TN 37831-0062, phone: (865 ) 576-8401, fax: (865) 576-5728, email: reports@ adonis.osti.gov 
TECHNICAL DIVISION

SAVANNAH RIVER LABORATORY
DPST $-82-836$

ACC. NO. 150227

$\underline{M} \underline{E} \underline{M} \underline{O} \underline{R} \underline{A} \underline{N} \underline{D} \underline{U} \underline{M}$

CC: J.A. Kelley, 773-A

J. F. Ortaldo, 773-A

M. J. Plodinec, 773-A

M. D. Boersma

F. M. Heckendorn

P. L. Graf

L. F. Landon

R. B. Ferguson

T. Motyka

D. C. Witt

H. L. Hull

D. P. Lewis

D. M. Sabatino

G. A. Griffin

C. T. Randa 11

H. C. Wolf

W. P. Colven

W. E. Carpenter

H. F. Sturm, Jr.

T. A. Willis

K. R. Routt

TIS File (2)

December 27,1982

TO: F. H. BROWN

FROM: c. R. POUNDCPty

\section{PRESSURIZED VESSEL SLURRY PUMPING}

\section{Introduction}

In the reference Defense Waste Processing Facility (DWPF) an abrasive slurry of frit and sludge is fed to the melter through a small tube (3/8-inch to $1 / 2-$ inch dia.) connected to a pressurized recirculating pipe loop. 1 Flow rate to the melter is controlled 
by regulating pipe loop pressure developed by a centrifugal pump. Severe abrasion of the pump impeller, casing, and seal during initial testing resulted in early pump failure. 2 A peristaltic pump unsuited for long term exposure to radioactive materials was used temporarily to feed the melter pending resolution of the abrasion problem.

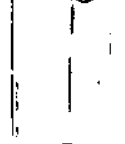

This memorandum summarizes testing of an alternate "pressurized vessel slurry pumping" apparatus, (Filgure 1). The principle is similar to rural domestic water systems and "acid eggs" used in chemical laboratories in that material is extruded by displacement with compressed air. Also included are a future equipment development program and appropriate design recommendations for adapting this principle to DWPF canyon operation.

\section{Summary and Conclusions}

Extrusion of slurry from a sealed agitated tank pressurized with compressed air is a viable method for continuous metering of frit-sludge slurry to a melter. The severe erosion problem and sensitivity to slurry rheology expected with centrifugal pumps are effectively avoided. Wear is minimized by low fluid velocities, and pumping characteristics are insensitive to wear.

A wide range of slurries were tested as follows:

- Consistencies from 8 to 49 centipoises

- Yield stresses from 58 to 511 dynes $/ \mathrm{cm}^{2}$

- Solids from 40 to 48 wt $\%$

- Fine and coarse frits, -200 to +100 mesh

- Formic acid treated, and untreated. 
These were transported through 1/4-inch, 3/8-inch, and 1/2-inch diameter tubes (Figures 4 thru 11). Flow rates were controlled by varying air pressure. Line pluggage in the small lines due to settling solids did not occur even at fluid velocities $<0.25 \mathrm{ft} / \mathrm{sec}$. All except one instance of line pluggage was attributable to lumpy material and debris in the slurry. The exception occurred in a "dead leg" (stagnant) section of 1-inch pipe.(Figure 14)

\section{Description of Equipment and Process}

The concept of the pressurized tank is the application of a constant overpressure of air which will force slurry continuously from the tank through the feed tube and nozzle into the melter. The initial equipment (Figure 1) designed to test this concept consisted of a 17 gallon tank which was proof tested to 150 psig. (Air system supply pressure was 90 psig, and safety considerations were satisfied by proof testing at least $1-1 / 2 \times 90=135 \mathrm{psig}$ ). A $1 / 2 \mathrm{hp}, 1750 \mathrm{rpm}$ agitator with three $4^{\prime \prime}$ diameter marine type impellers was used to maintain suspension of solids in the slurry. The agitator shaft was equipped with a packing gland seal to prevent excessive air leakage from the tank. Air supply was controlled by a pressure regulator. A back pressure regulator mainrained constant air pressure in the tank by bleeding air as the slurry level rose during filling. The tank was placed on weight scales so that the slurry level could be monitored. Initially, a small rate drum was used to decermine feed rate. In later experiments a magnetic flowmeter was also installed. 
Three sizes of feed tubing 1/4-inch, 3/8-inch, and 1/2-inchdiameter were tested to determine the effect of cross sectional area on pressure drop and line pluggage. Each tube was 77 feet long, and included four long radius $180^{\circ}$ bends, two long radius $90^{\circ}$ bends and four couplings. Any slurry transport system can be used to fill the tank. During this test a diaphragm pump with a 1 -inch discharge pipe was utilized. Calibrated pressure gages and duplicate the rmometers were used. Slurry takeoff was near the bottom of the pressurized tank to prevent accumulation of solids on the tank bot tom.

For flushing the system, ball valves were installed so that water could be flushed in either direction through the piping to the pressurized tank or feed nozzle. Similarly, the 1-inch supply line to the pressurized tank could be flushed with water.

\section{Water Tests}

Initial system checkout was performed using water (Figure 2). Characterization of the system with a Newtonian fluid simplified determination of equivalent tubing length and provided a familiar basis for comparison when later pumping slurry. Flow began at slightly less than 1 psig in all cases because at low velocities the 2 foot elevation head (Figure 1) constituted the major portion of the total head at the beginning of flow. The system behaved as anticipated verifying that flow could be controlled by varying air pressure. At a pressure of 25 psi, flow races were $0.34,1.22$, and $3.39 \mathrm{gpm}$, respectively, for $1 / 4-\mathrm{inch}, 3 / 8$-inch, and $1 / 2$-inch- 
diameter tubing. Corresponding fluid velocities were $4.28,5.34$, and 7.49 fps, respectively.

To determine equivalent tubing length the Darcy equation can be used. The Darcy equation can be stated as:

$$
\begin{gathered}
\mathrm{H}_{\mathrm{L}}=\mathrm{f} \frac{\mathrm{L}_{\mathrm{e}}}{\mathrm{D}} \frac{\mathrm{V}^{2}}{2 \mathrm{~g}} \\
\mathrm{H}_{\mathrm{L}}=\text { head loss, (ft of fluid) } \\
\mathrm{f}=\text { friction factor (from Moody diagram) } \\
\mathrm{D}=\text { tubing diameter, } \mathrm{ft} \\
\mathrm{V}=\text { fluid velocity, ft/sec } \\
\mathrm{g}=\text { gc }=32.2 \mathrm{ft} / \mathrm{sec} .2 \\
\mathrm{~L}_{\mathrm{e}}=\text { equivalent tubing length, ft }
\end{gathered}
$$

Thus,

$$
L e=\frac{2 g D_{L}}{E V^{2}}
$$

A pipe roughness of 0.00007 inch was assumed. 3 The Reynolds numbers ( $R e$ ) were computed, and the friction factors ( $f$ ) were obtained from the Moody diagram. Thus, equivalent tubing lengths (Le) of about 90 to 100 feet were determined by iterative substitution in the Darcy equation (Tables 1, 2, and 3 ).

\section{Slurry Tests - TDS Sludge, Frits 131 and 140}

Slurries were a 28 wt \% solids (on oxide basis) simulated waste sludge 4,5 combined with either Frit $131^{5}$ or Frit $140^{6}$ (Appendix A). Both formated and unformated were run. The formaced feeds were made by $E$. J. Weber 
in the large scale slurry mix evaporator.7 Many of the slurry properties were varied to determine the effect on pumping characteristics. Frit sizes ranged from -200 to +100 mesh and yield stresses from 58 to 511 dynes $/ \mathrm{cm}^{2}$ (as determined with the "Haake Rotoviscometer").

Waste slurry properties resemble those of a Bingham plastic in that higher shear stresses, and greater pressure drops in pipe are required to initiate flow than with Newtonian fluids such as water (Figure 3). For example, pressures in the range of 7 to 31 psi as compared with 1 psi with water were required to initiate flow with six slurries rested in three tube sizes (more about this later under Rheology, page 9)

\section{- Formated vs. Nonformated Slurry}

Two batches of sludge-frit slurry containing Frit $131,-80$ mesh were tested. One batch was treated with formic acid, and one was untreated. Each batch was run through the three tube sizes (Figures 4, 5, and 6). Flow began at about 13,16 and 21 psi with the treated material, and at about 10, 16, and 25 psi with untreated material in $1 / 2-$ inch, 3/8-inch, and $1 / 4-$ inch tubing, respectively (Slurry batches 1 and 2 , Table 4 ). Thus, about the same pressures were required to initiate flow with both batches. The general conclusion is that treatment of slurry with formic acid affects the actual yield stress very little although the Haake determinations indicated 100 vs. 190 dynes $/ \mathrm{cm}^{2}$ for treated and untreated, respectively. Significant pressure 
differences exist at higher flow rates. In all tube sizes (Figures 4, 5, and 6), the pressure drop for formate treated material was less at low flow rates, and greater at high flow rates than with untreated material, i.e.; the curves cross. This is not understood.

At the reference flow rate of $1 / 2 \mathrm{gpm}$, (DWPF melter feed will be $1 / 2$ gpm through each of two feed nozzles) pressure drops were lowest with the treated material. They were 16 and 33 psi through $1 / 2$ and $3 / 8$ tubes, respectively, with the treated material and 19 and 36 psi, respectively, with untreated material. Corresponding fluid velocities were 1.1 and 2.2 $\mathrm{ft} / \mathrm{sec}$ for $1 / 2$ and $3 / 8$ tubes respectively. At pressures of 70 to $80 \mathrm{psi}$, only about $1 / 4 \mathrm{gpm}$ flowed through $1 / 4$-inch tubing. Thus, 1/4-inch diameter tubing is impractical for feeding the melter at $1 / 2$ gpm because of the high pressure required.

\section{- Unformated Slurry with Coarse Frit}

Two batches of sludge-frit slurry containing Frit $131,50 \%$ -100 mesh, and $50 \%-50+100$ mesh were tested with $1 / 2-$ inch, $3 / 8-$ inch, and 1/4-inch diameter tubing (Figures 7,8 , and 9). A 41 wt \% slurry was divided into two batches (batches 3 and 4 , Table 4). The thicker, more dense batch No. 4 was prepared by decanting water to final 48 wt $\%$ solids.

The pressure required to initiate flow was about the same with both batches. As anticipated, pressures required for the reference flow rate of $1 / 2 \mathrm{gpm}$ are lower for the 41 wt \% than 
the 48 wt \% material. They were 22 vs. 24 psi with $1 / 2$-inch tubing, and 35 vs. 48 with $3 / 8$-inch tubing (Figures 7 and 8 ). The reference flow rate was not attained with 1/4-inch tubing. At 85 psi flows were only about $1 / 3 \mathrm{gpm}$ with 41 wt. \% slurry, and $1 / 8$ gpm with 48 wt $\%$.

\section{- Unformated Slurry with Fine Frit}

Two batches of sludge-frit slurry containing Frit $140,-200$ mesh were tested with $1 / 2$ and $3 / 8$-inch tubing. One batch contained 47 and the other 39 wt \% solids. The thicker more dense slurry had a yield stress of 511 dynes $/ \mathrm{cm}^{2}$ and consistency of 49 centipoises, while the other had a yield stress of 58 dynes $/ \mathrm{cm}^{2}$ and consistency of 8 centipoises. Rheologies were determined with the Haake Rotoviscometer (See Rheology later in report). Pressures required to initiate flow in the $1 / 2$-inch tube were about $10 \mathrm{psi}$ for the more dense material and about 7 psi for the other (Table 4 batches 5 and 6 ). Flow began at $10 \mathrm{psi}$ in 3/8-inch tubing with the less dense slurry. The thicker more dense material was not run in the $3 / 8$-inch tube, and neither material was run in $1 / 4-$ inch tubing.

Pressures required for the reference flow rate of $1 / 2 \mathrm{gpm}$ in 1/2-inch tubing was 45 psi for the more dense material and $10 \mathrm{psi}$ for the other (Figure 10). A flow of $1 / 2 \mathrm{gpm}$ of the less dense material in $3 / 8$-inch tubing required a pressure of $31 \mathrm{psi}$ (Figure 11). 


\section{Other Areas of Investigation}

- Rheology

Slurry rheological properties were determined using a Haake

Rotoviscometer. This apparatus employs a rotating cylinder in a close fitting sample cup. The torque requirement is measured as the speed of the rotor is varied. Torque versus RPM is translated into a rheogram that is shear stress versus shear rate. The rheogram shows yield stress ( $\tau y$, dynes $/ \mathrm{cm}^{2}$ ) and consistency, ( $n$, centipoise).

Several haake runs were made for each slurry batch tested in the pressurized tank facility. The Haake produced erratic rheograms and showed considerable variacion in yield stress and consistency, even for samples from the same batch. This is probably the result of settling and/or grinding of the frit in the instrument's small clearances. For example, Table 5 shows the results of multiple Haake runs of two different slurries, one formic acid treated and one untreated. Standard deviations ( $\sigma$ ) for yield stresses were 17.4 and 74.4 , respectively. Standard deviations for consistencies were 5.8 and 6.1 , respectively. Variance in solids concentrations and density, also shown in Table 5 , is low.

A more reliable determination of rheological properties is needed. Alternatives to the Haake Rotoviscometer include: 
- A suitable instrumented/calibrated pressurized tank system.

Georgia Iron Works Hydraulic Laboratory employs a similar "extrusion" rheometer which accurately predicts performance. 8

- A smaller capillary viscometer, such as the one developed at SRL. 9

If Haake-generated rheological properties (yield stress and consistency) are used to predict pressure drop, the results vary considerably from data obtained in the pressurized tank facility. For example, Figure 12 compares data from an actual run to the values that would be predicted from the Haake data. The actual pressure drop is considerbly lower than the predicted values.

One reason for this disagreement is error in determination of rheological properties with the Haake. Also, the correlations used to predict Bingham $\mathrm{Plastic}$ behavior are mathematical conveniences, but do not always accurately represent our slurries, especially at very low flow rates. A typical Bingham Plastic will have an actual yield stress about $25 \%$ lower than the theoretical. Waste slurry simulations tested at Georgia Iron Works showed no actual yield stress, even when the nominal yield stress was high. 8 The nominal value can often be used to predict pressure drop through most of the laminar region, but not at the very low flows. These concepts are illustrated in Figure 13.

\section{- Line Plugging and Location of Valves}

One instance of line pluggage occurred in a 10-foot-long "dead leg" section of 1-inch piping between a pipe tee and block valve 
(Figure 14). Application of 120 psi water pressure failed to dislodge it. The pluggage was removed by rodding, and it consisted of a small percentage of sludge mixed with coarse frit particles (mostly $+100,-50$ mesh) firmly packed. No further plugging occurred after the valve was relocated 6-inches from the cee. This indicates that 2-way valves are satisfactory for slurry service but should be located close to junctions. Also, plugging did not occur in the 10-foot-long "dead leg" when handling slurry containing the finer -80 and -200 mesh frits. Apparently, most of the finer particles remained suspended in the fluid stream as it passed through the tee, but some of the coarse particles settled into the "dead leg" and formed the plug. All other instances of plugging were attributable to dried lumps of slurry or debris, such as fragments of rubber and plastics. The dried lumps formed in the open rate drum and the partially covered mix tank (Figure 1). Straining slurry through 14 mesh screen eliminated the problem. A separate program is underway to develop a slurry filter or strainer system which will be applicable to DWPF canyon operation.

On several occasions the tank and piping remained filled with slurry with the agitator stopped during weekend shutdowns (64 to 90 hrs). Flow restarted without difficulty in every instance. On one occasion the system remained filled (with unformated slurry, batch No. 2, Table 4) during a 7-day shutdown. Flow restarted slowly after about 10 seconds at 50 psi tank pressure. 
Initially, the material was very thick and contained soft lumps.

Full flow was restored within $1 / 2$ minute. However, 72 feet of the cubing ran horizontally, and only 5 feet ran vertically. Vertical tubing might be more susceptible to plugging as a result of settling of solids during shutdowns. In any event, water flushing the system may not be required prior to short shutdown periods when handling slow settling slurries.

\section{- Slurry Deposits on Tank Walls and Lid}

Thick "mud like" deposits of slurry were observed on the underside of the flanged tank cover. Similar deposits existed above the liquid level in the large slurry storage tanks in Building 675-G. The deposits apparently resulted when water drains from slurry splashed against the tank walls. While wet and soft the material recombined easily with the slurry. If allowed to dry, it can form lumps and cause line plugging. 7

\section{- Agitation}

The 12-inch pressurized tank was equipped with an agitator located off center. This was done to avoid using tank baffles because slurry tends to "cake up" on them. The agitator was stopped for short periods without apparent adverse effect indicating that continuous operation may not be necessary with slow settling slurries. Adequate agitation might be provided by frequent addition of slurry near the tank bottom, thus, incorporating and mixing the slurry heels with the newly introduced material. 
Advantages would be extended useful life of agitator motor, impellers, and shaft seal.

\section{- Abrasion and Erosion of Impellers}

A $1 / 2 \mathrm{hp}, 1750 \mathrm{rpm}$ agitator was mounted off center in the 12inch tank. The off center location limited impeller diameters to 4 inches maximum. Thus, three 4 -inch diameter marine type. impellers of Type 316 stainless steel were mounted 10 inches, apart on the 3/4-inch diameter shaft. After 500 hours of operation at tip speeds of 1600 to $1800 \mathrm{ft} / \mathrm{min}$., the impellers were worn sharp at the edges and reduced to 3-1/2-inch diameter with a $15 \%$ weight loss ( 130 to 110 grams).

The high impeller tip speeds (A. W. Etchells of ESD recommended a maximum of $600 \mathrm{ft} / \mathrm{min}$ ) were required to maintain agitation in the off-center location. A larger tank would permit larger diameter impellers and lower tip speeds.

\section{FUTURE SYSTEM AND PROGRAM}

A similar but larger 2-foot-diameter $\times 3$-foot-high (70 gallons capacity) pressurized-tank, slurry-feed system (Figure 15) has been fabricated for further testing of this concept. Areas of investigation follows:

\section{- Flow Control and Tank Filling}

In previous tests the tank sat on weight scales and was periodically refilled by manually starting a pump. Flow to the melter was monitored by a magnetic flow meter and controlled by manual 
adjustment of tank air pressure. The flow rate varied (reduced) slightly between tank fillings (Figure 16). This happened because the lowering fluid level in the tank resulted in a corresponding reduction in available pressure head. No adverse conditions resulted from these small variations. It could be corrected by simultaneous increase of air pressure as the slurry level in the tank decreased.

The new (24-inch-diameter) system incorporates a Hewlett-Packard micro computer and appropriate accessory apparatus specified by F. M. Heckendorn and programed by D. M. Sabatino. This equipment will be used to control slurry flow rates and tank filling automatically. Outputs from load cells will be utilized in the computer program to effect control. Similarly, output to the computer from a magnetic flowmeter will be evaluated for flow control. Also, a separate liquid level probe will be evaluated.

\section{- Agitation}

With the new equipment the slurry can be added to the tank at the sides near the top or bottom, and at points between top and bottom. As previously mentioned, the objective is to determine if an inrushing slurry stream will adequately mix with the slurry heel and maintain solids suspension without mechanical agitation. The new equipment also permits variable speed mechanical agitators to be mounted on the tank centerline or off-center. Tank baffles are removable. 
- Line Plugging and Settling of Solids

Plans are to determine if solids settle in long vertical tubes during extended shutdowns and cause line plugging.

\section{- Slurry Strainer}

The problem of eliminating or removing debris from slurry streams in a radioactive canyon environment will be addressed.

- Slurry Deposits on Tank Walls and Lid

The new 24-inch-diameter tank design incorporates a slinger on the center mounted agitator shaft. Provision is made for periodically directing a stream of water and/or slurry onto the rotating slinger so that it will be centrifugally spread to the tank wall. Expectations are that this will wash thick slurry deposits from the tank cover and walls. 


\section{References}

1. Technical Data Summary, DPSTD-80-38-2.

2. CMOG Report No. 5 .

3. Crane technical paper No. 410, and Du Pont Std. D6 2.38, Table 1.

4. DPST-81-484, Table 2 .

5. DPST-82-624, Table 2 .

6. DPST-80-402, Table 6 .

7. DPST $-82-733$.

8. DPST-82-954, DPST-82-955.

9. Unpublished work by T. Motyka. 


\section{Acknowledgements}

Appreciation is expressed to:

W. L. I som and D. J. Trapp for design assistance.

D. P. Lewis for assistance in evaluating test data.

D. M. Sabatino for assisting in equipment operation and preparing operating procedures.

\section{Quality Assurance}

All data in this report may be used for design purposes.

Measurements were taken with calibrated and/or dual sensors. Data

and pertinent informatin are recorded in research notebooks

DPSTN-1500, 4046, and QA files. Equipment design details are shown

on Drawings SX5-00196, 00522 , and 00523 . 



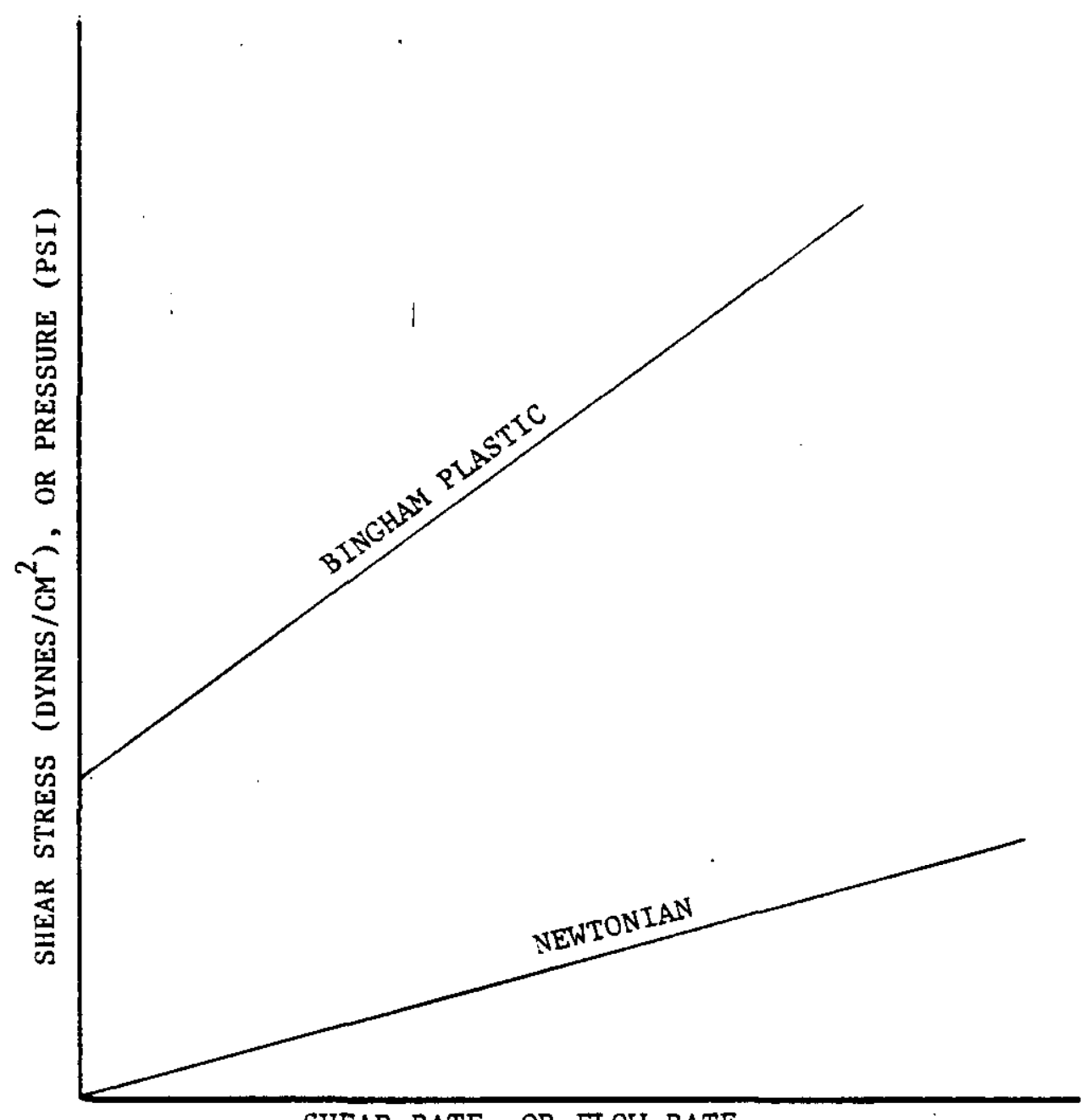

SHEAR RATE, OR FLOW RATE

FIGURE 3 
VELOCITY (FT./SEC.)

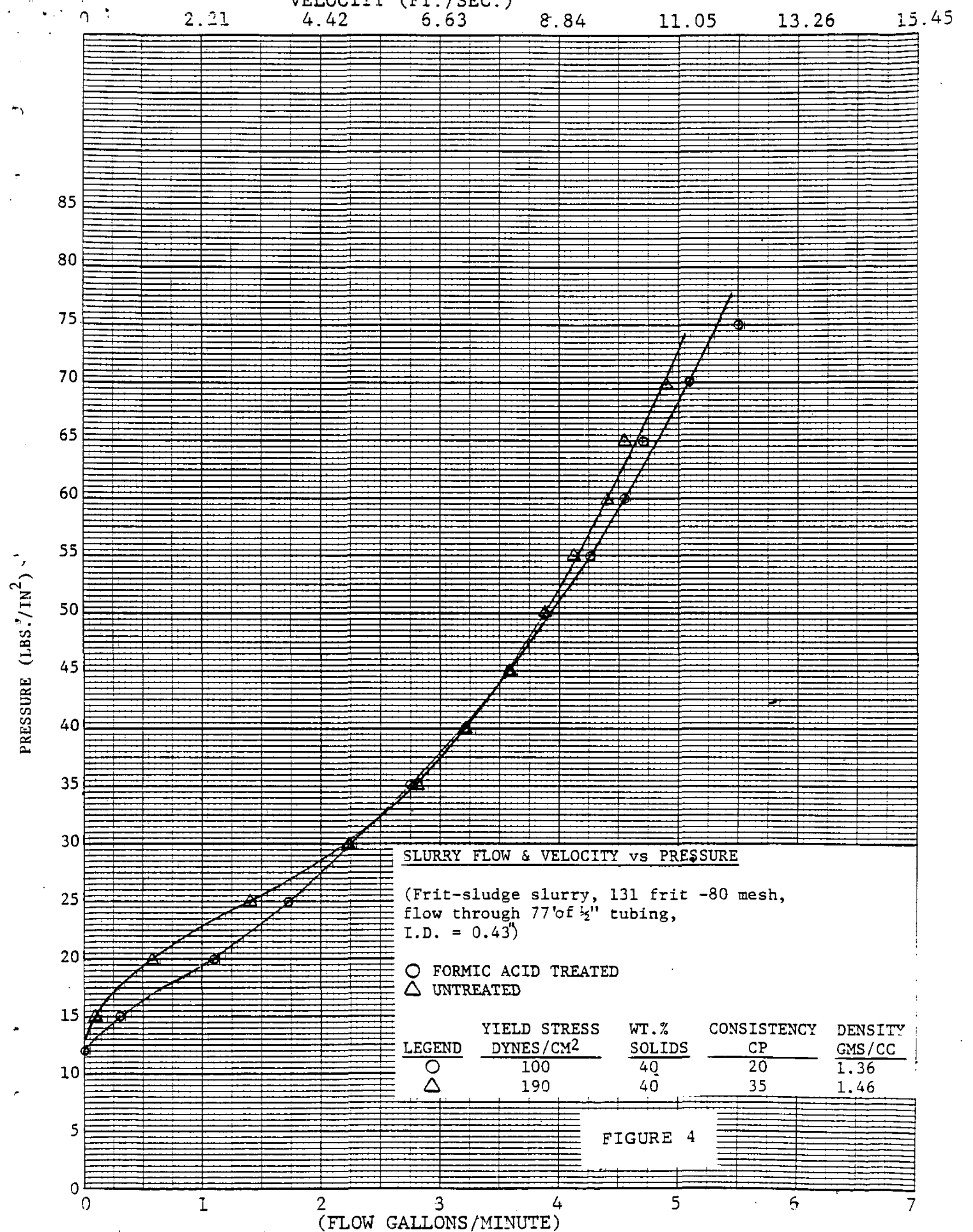




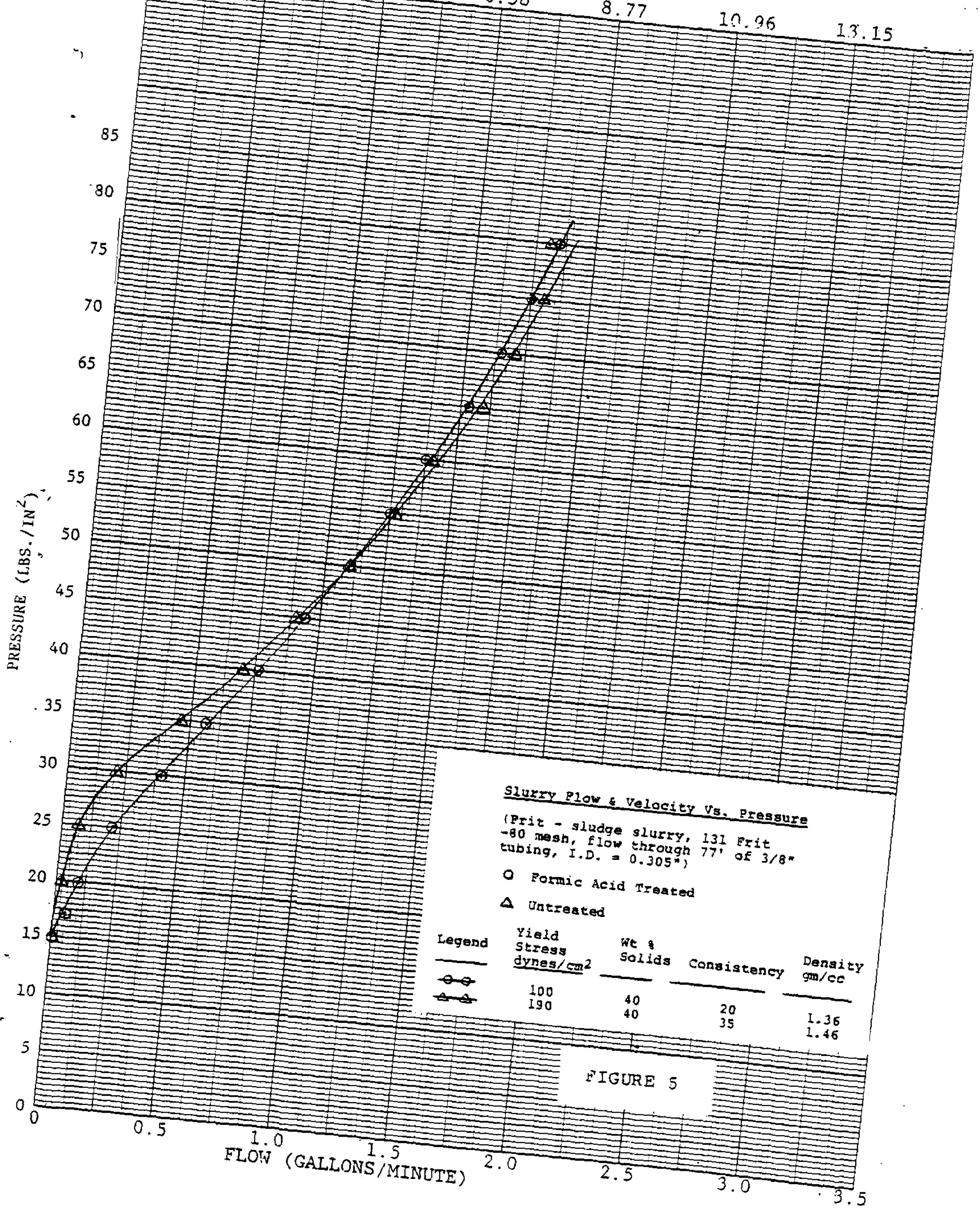



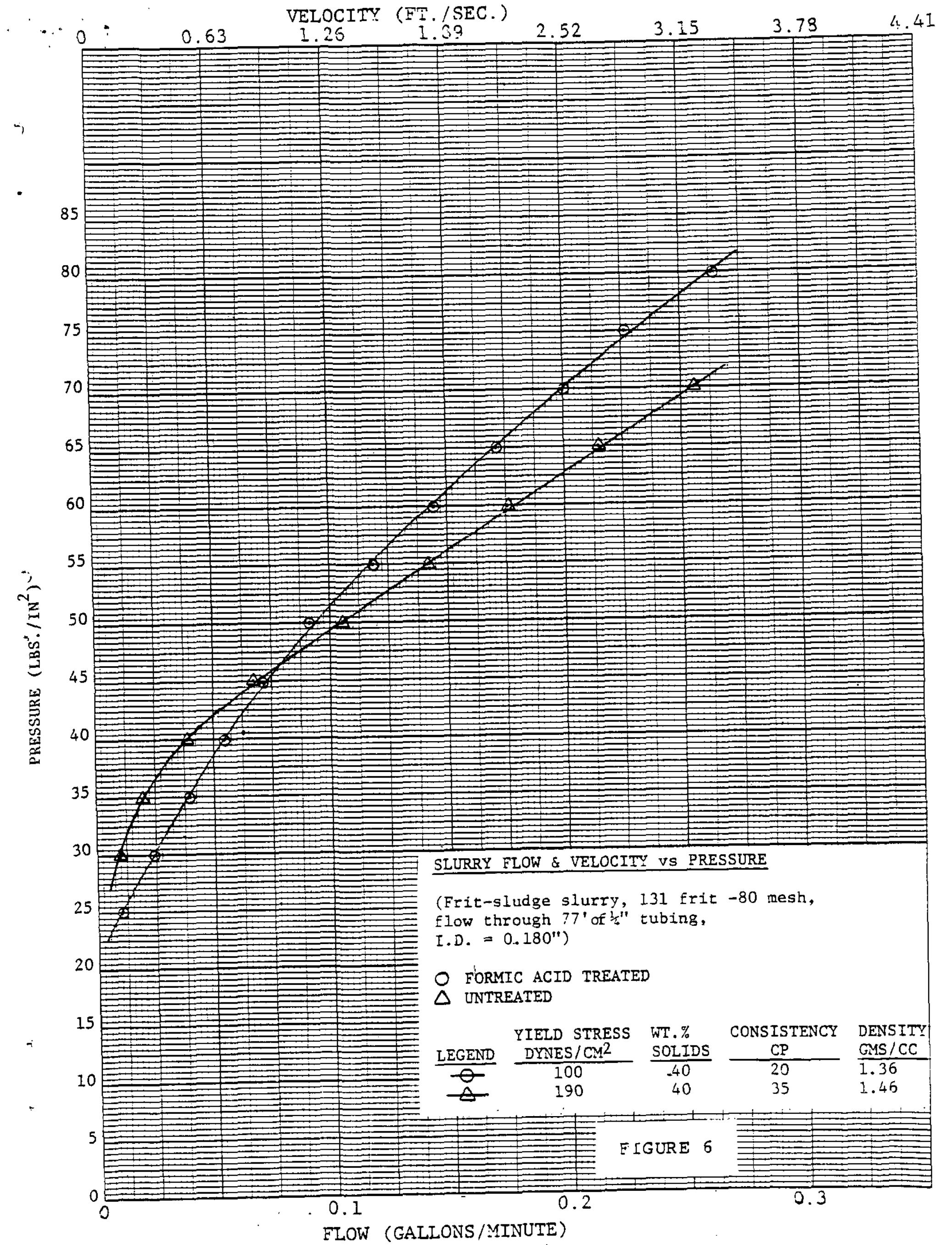
VELOCITY (FT./SEC.)

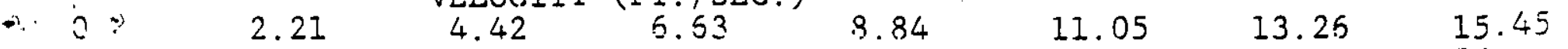

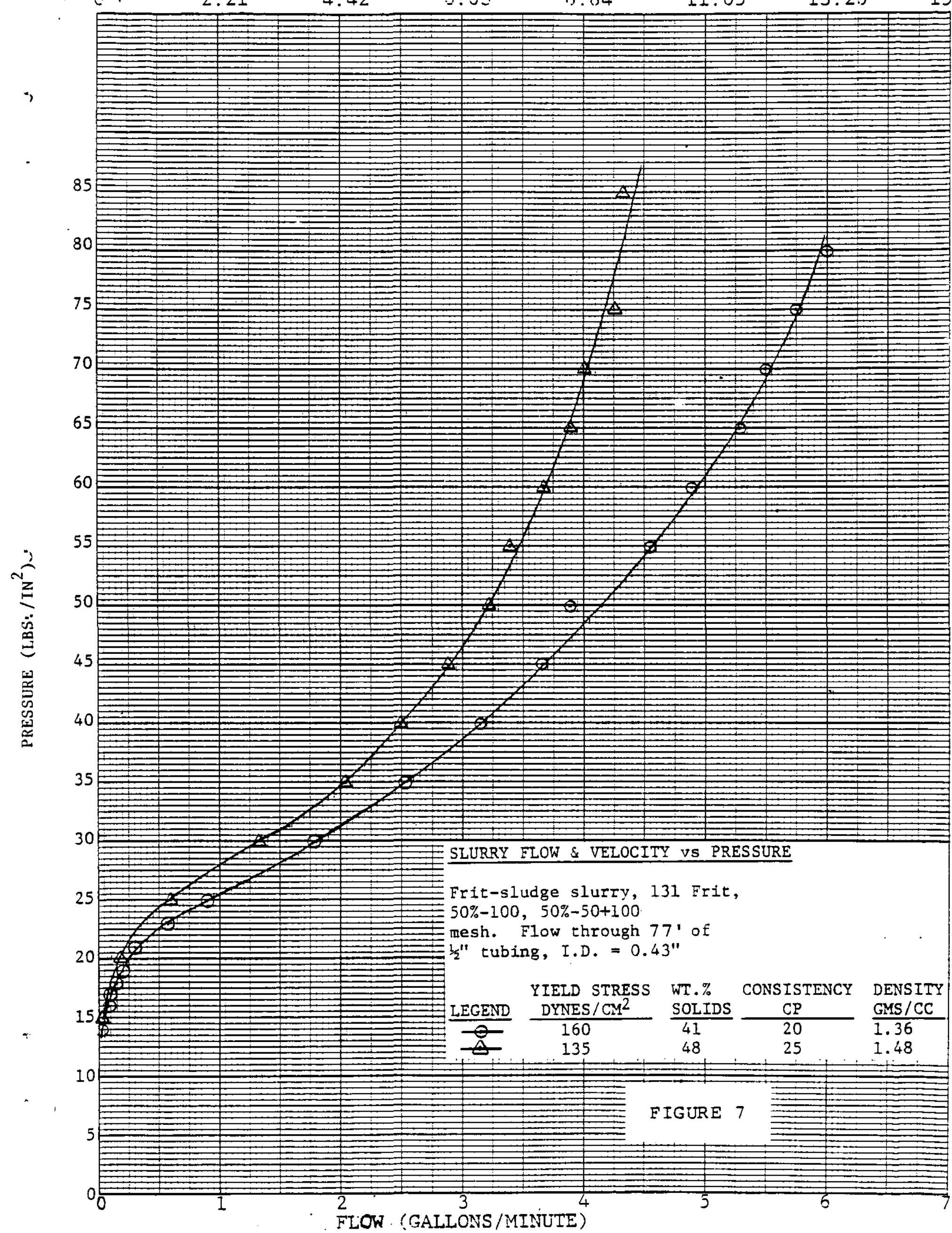


VEIOCITY (ET./SEC.)
$\cdots 0$
4.39
5. 58
8.77
10.96
13.15

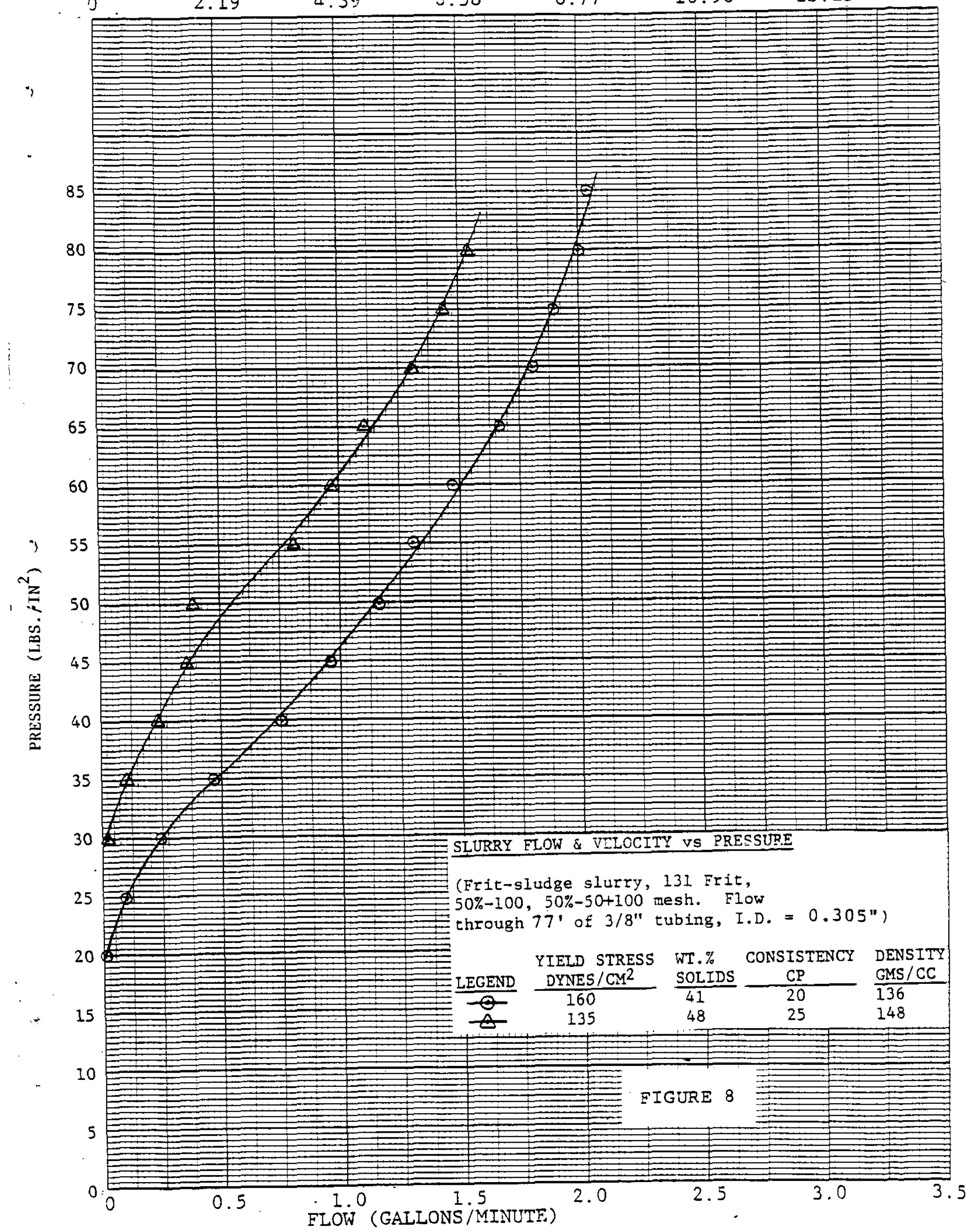




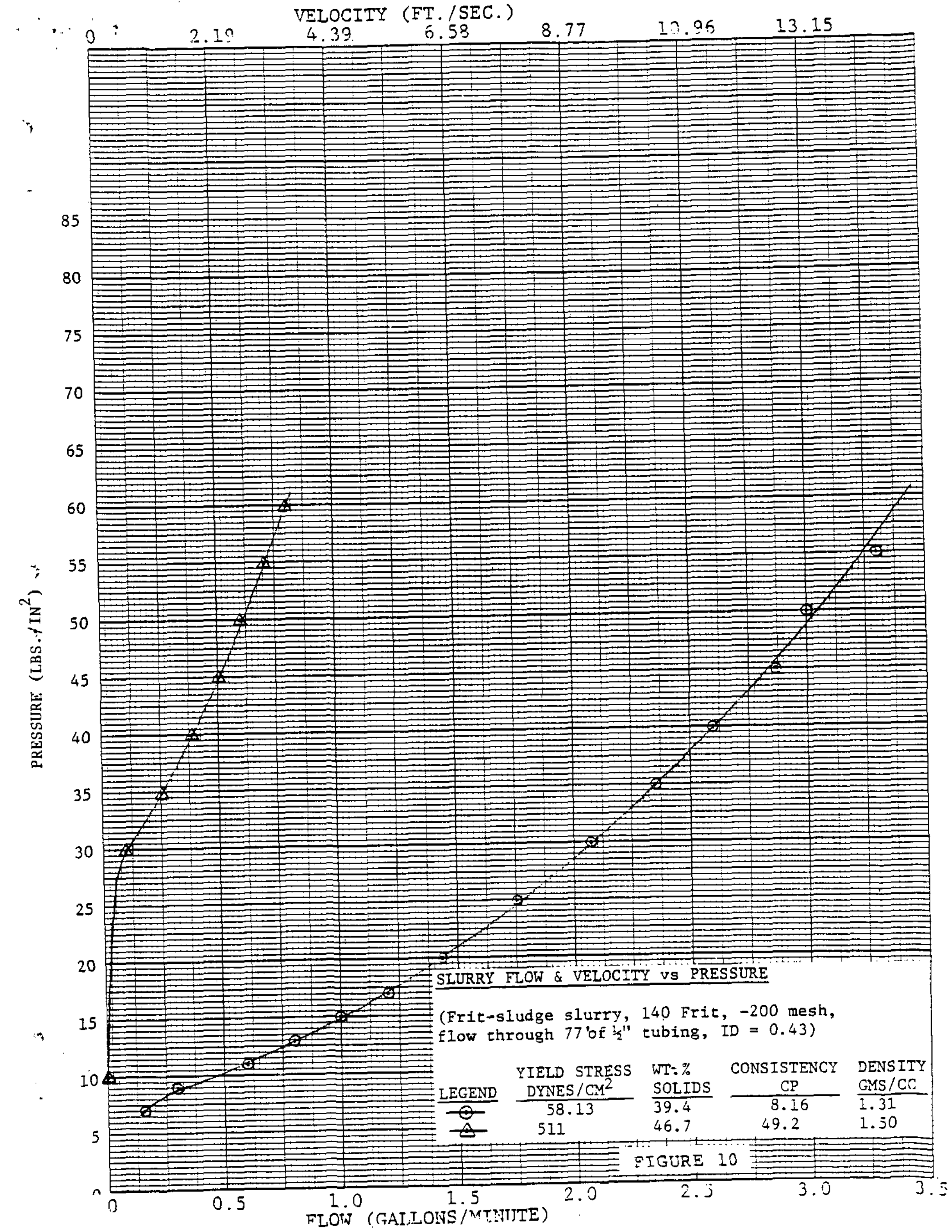




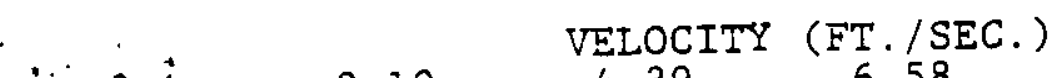
$\therefore 0$
2.19
4. 39
6.58
8.77
10.96
13.15

85

30

75

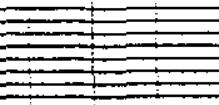

70

55

60

55

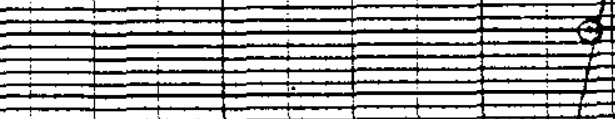

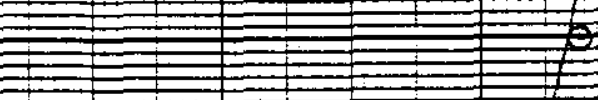

2

50

45

11212

$\square \leq 1$
151

11

$\square 0019$
210109

0

1121
1121

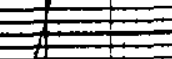

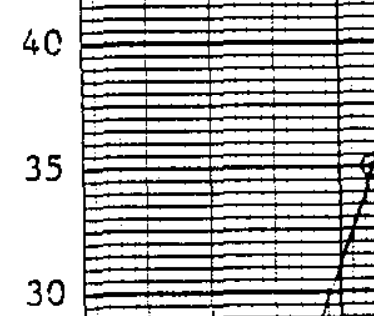

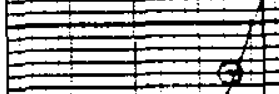

25
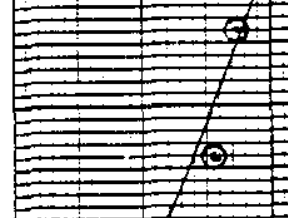

20

2.5
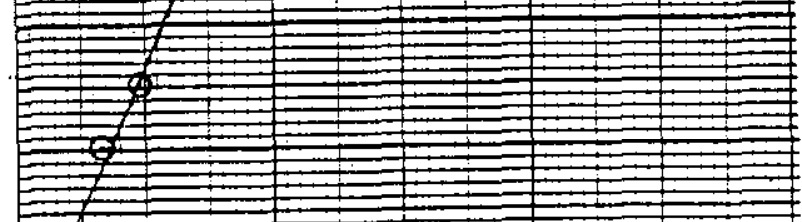

D

DYNES/CM ${ }^{2}$ SOLIDS $\quad$ CP GMS/CC

10

58.13

OW \& VELOCITY VS PRESSURE 


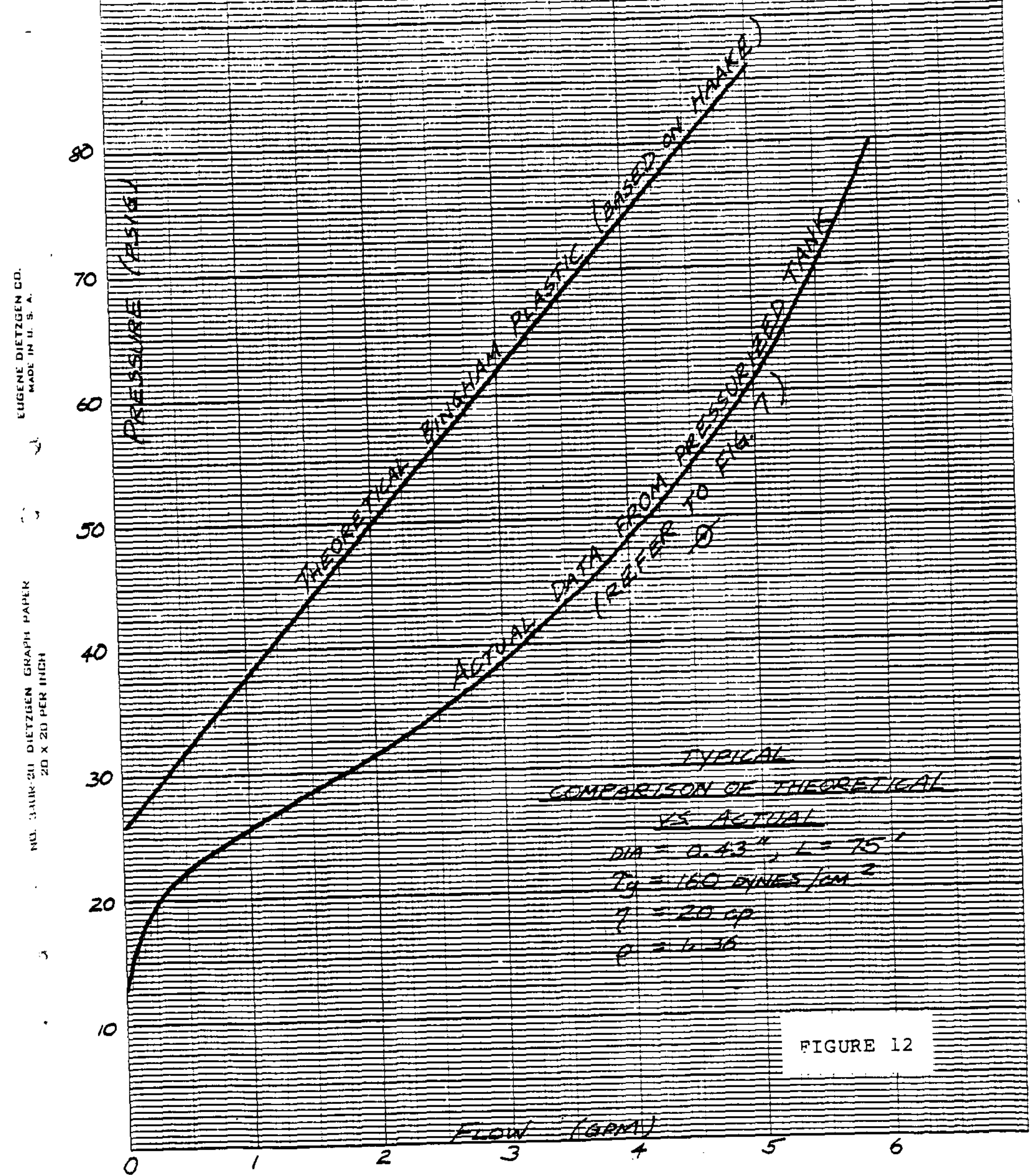




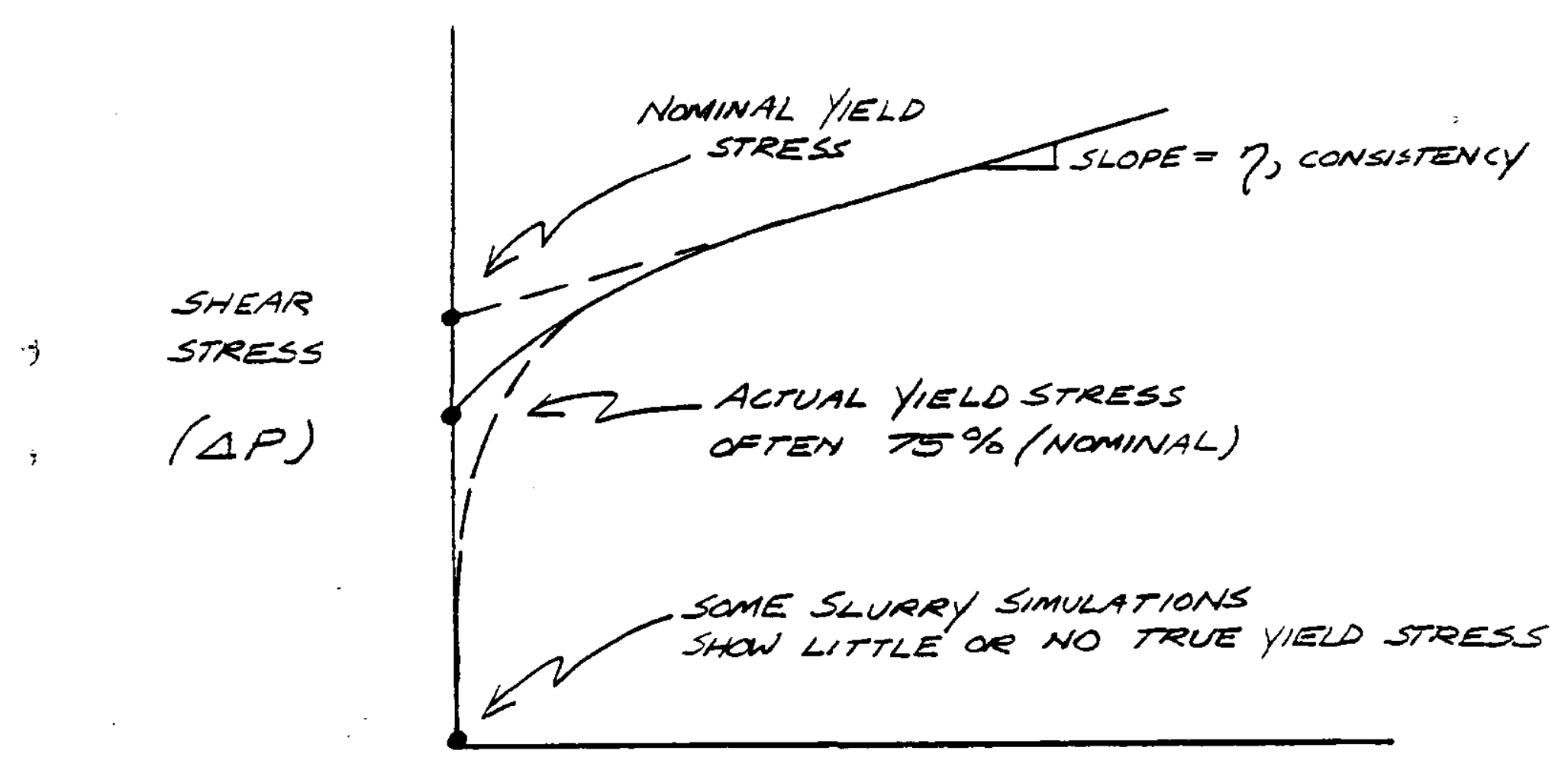

SHEAR (FLOW) RATE

GENERALIZED FLOW DIAGRAM

FIGURE IS 

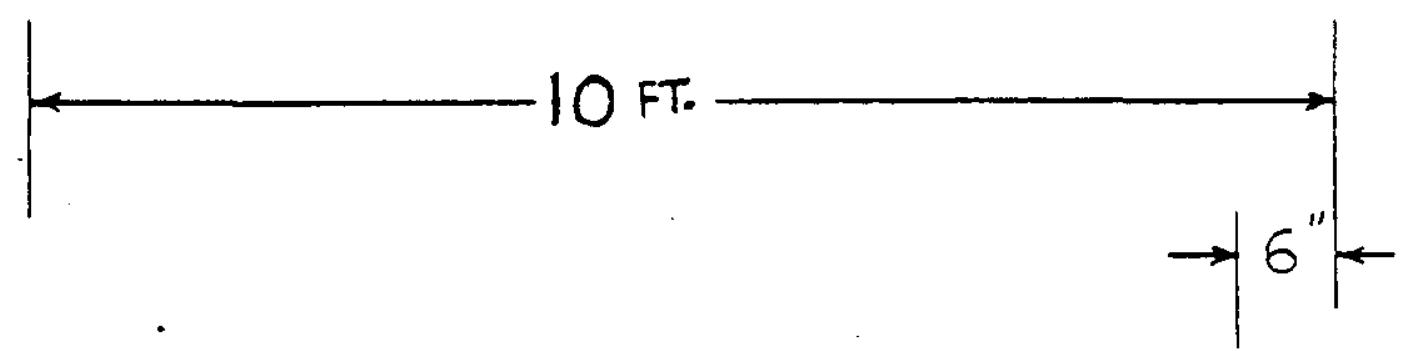

y

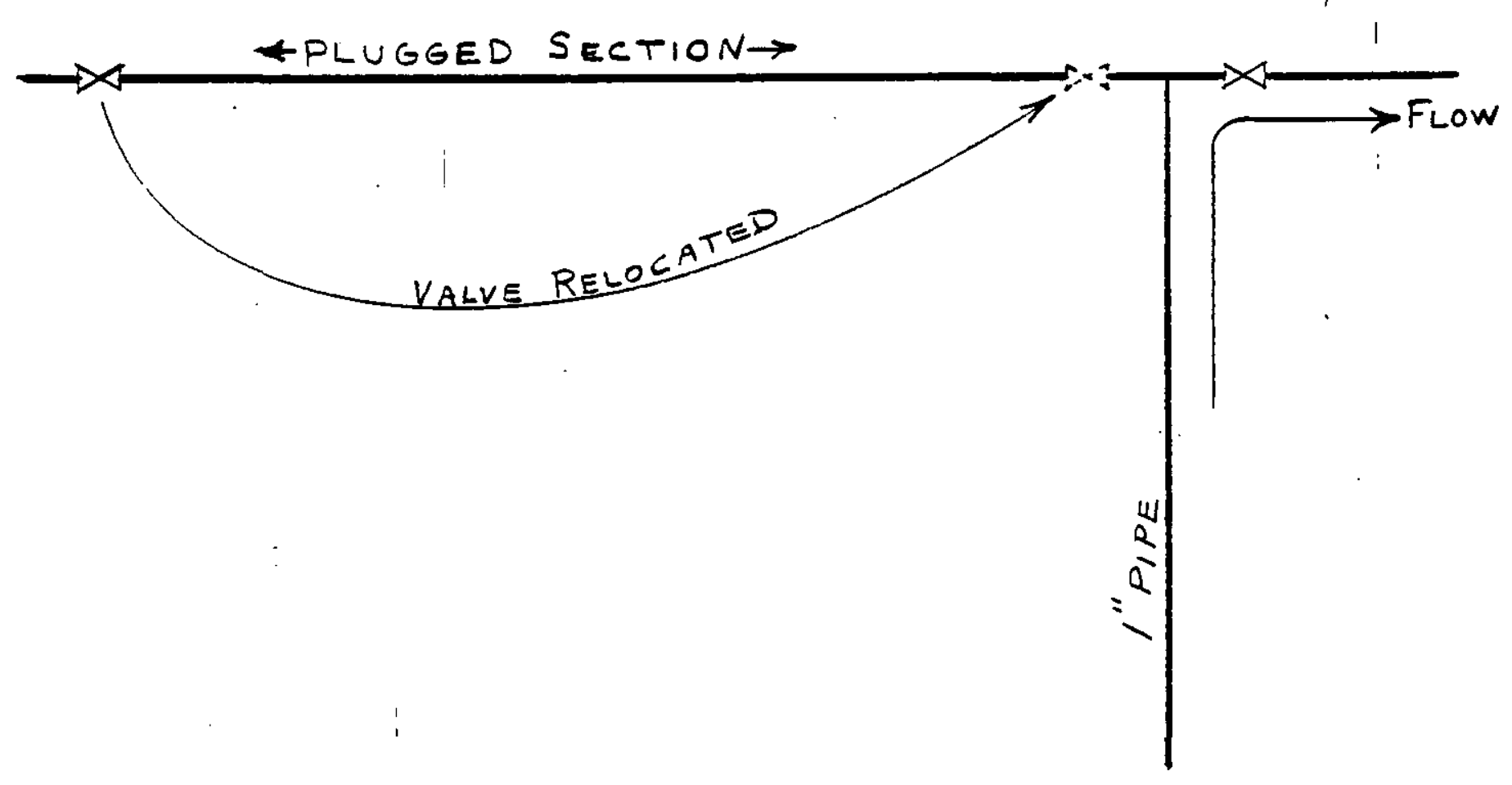

FIGURE 14 


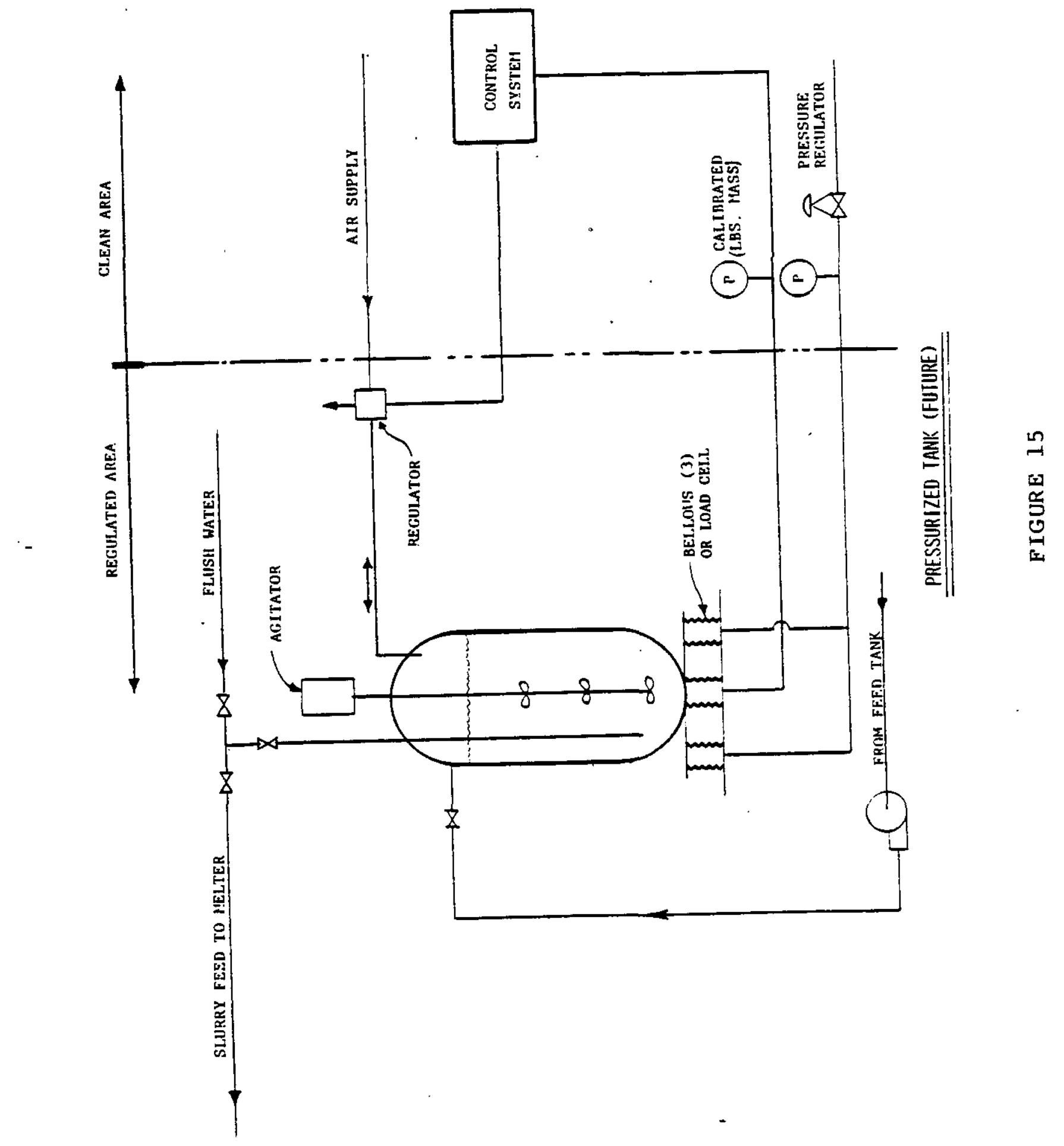




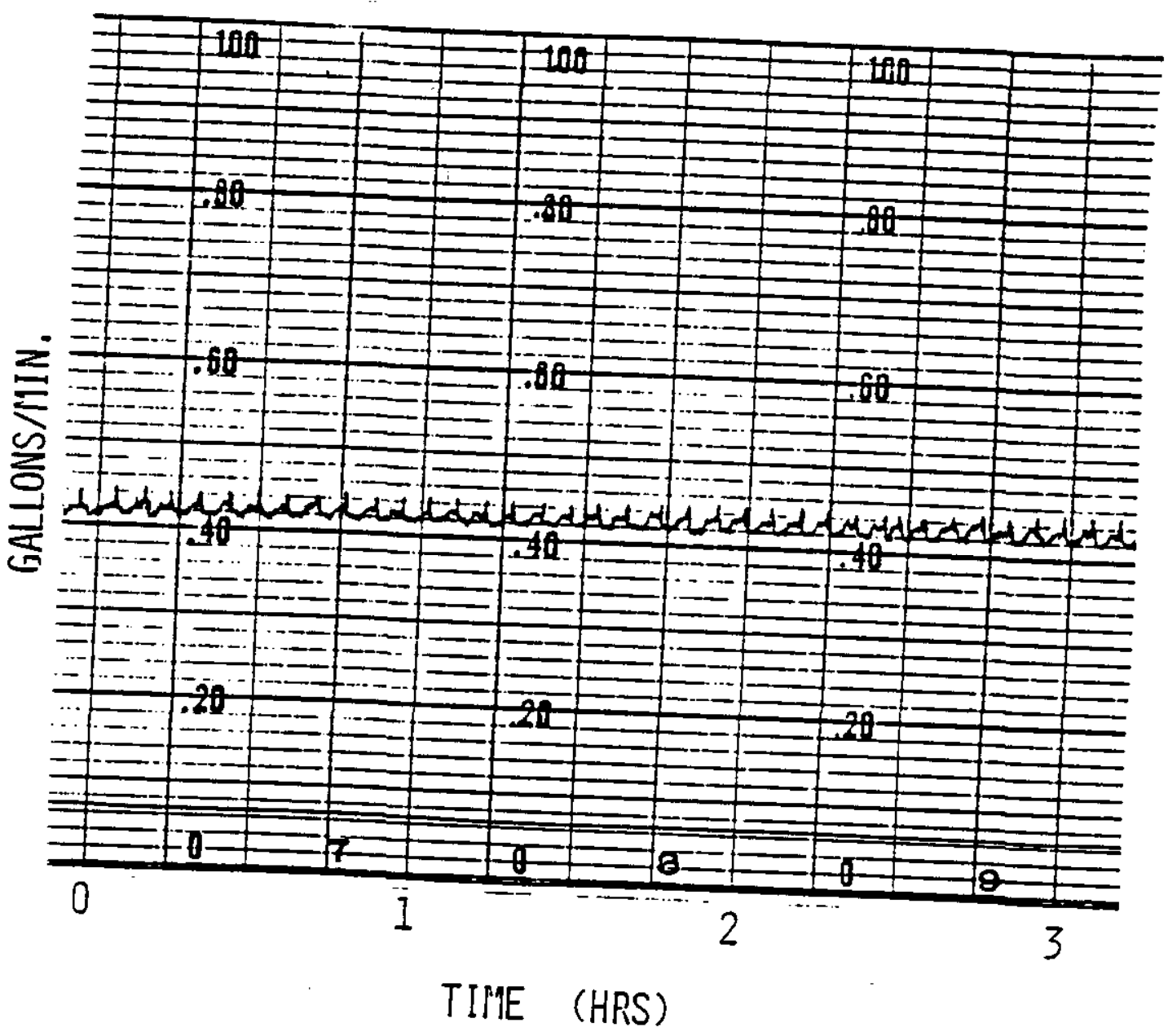

FIGURE 16 
TABLE 1

(For Water Flow in 1/2-inch 0.D., 0.430-inch I.D. Tubing)

\begin{tabular}{|c|c|c|c|c|c|c|}
\hline $\begin{array}{c}\text { Pressure } \\
\left(\text { lbs } / \text { in }^{2}\right) \\
\star\end{array}$ & $\begin{array}{l}\text { Velocity } \\
(\mathrm{ft} / \mathrm{sec})\end{array}$ & $\begin{array}{l}\text { Reynolds } \\
\text { (Re) }\end{array}$ & $\begin{array}{c}E / D \\
(\text { in } / \text { in }) \\
\star \star\end{array}$ & $f_{\star \star \star *}$ & $\begin{array}{l}\mathrm{H}_{\mathrm{L}} \\
\left(\mathrm{f}_{t}\right) \\
\star * \star *\end{array}$ & $\begin{array}{l}\text { Le } \\
(f t)\end{array}$ \\
\hline 1.4 & 1.075 & 3966 & 0.000163 & 0.0397 & 1.27 & 63.9 \\
\hline 1.8 & 1.233 & 4598 & 0.000163 & 0.038 & 2.16 & 84.8 \\
\hline 2.0 & 1.3 & 4792 & 0.000163 & 0.0375 & 2.63 & 97.1 \\
\hline 2.4 & 1.59 & 5865 & 0.000163 & 0.035 & 3.55 & 93.5 \\
\hline 3.4 & 2.085 & 7692 & 0.000163 & 0.0325 & 5.86 & 96.5 \\
\hline 4.4 & 2.55 & 9388 & 0.000163 & 0.031 & 8.17 & 94.5 \\
\hline 5.4 & 2.79 & 10292 & 0.000163 & 0.030 & 10.49 & 104.1 \\
\hline 6.4 & 3.15 & 11617 & 0.000163 & 0.029 & 12.8 & 103.1 \\
\hline 7.4 & 3.534 & 13037 & 0.000163 & 0.285 & 15.11 & 98.3 \\
\hline 8.4 & 3.742 & 13804 & 0.000163 & 0.28 & 17.42 & 102.9 \\
\hline 9.4 & 4.131 & 15239 & 0.000163 & 0.275 & 19.74 & 97.4 \\
\hline 10.4 & 4.298 & 15855 & 0.000163 & 0.27 & 22.05 & 102.3 \\
\hline 12.4 & 4.894 & 18054 & 0.000163 & 0.265 & 26.68 & 97.2 \\
\hline 15.4 & 5.484 & 20230 & 0.000163 & 0.26 & 33.62 & 99.4 \\
\hline 20.4 & 6.492 & 23949 & 0.000163 & 0.245 & 45.18 & 101.2 \\
\hline 25.4 & 7.574 & 27940 & 0.000163 & 0.24 & 56.75 & 95.3 \\
\hline 29.4 & 8.371 & 30880 & 0.000163 & 0.235 & 66.00 & 92.6 \\
\hline
\end{tabular}

* Pressure from Figure 2.

** $E=0.00007$ inch (CRANE Technical Paper 410 and Du Pont Std DG $2.3 \mathrm{~B}$, Table 1 ), $E / D=$ relative roughness, $D=$ tubing $I \cdot D$. (inch).

*** $f$ - friction factor from MOODY diagram.

$\star \star \star *(2.313 \times$ Pressure $)-2$, see $2^{\prime}$ dimension Figure 1 . 
TABLE 2

(For Wacer Flow in 3/8-inch O.D., 0.305-inch I.D. Tubing)

\begin{tabular}{|c|c|c|c|c|c|c|}
\hline $\begin{array}{c}\text { Pressure } \\
\left(1 \mathrm{bs} / \text { in }^{2}\right) \\
\star\end{array}$ & $\begin{array}{l}\text { Velocity } \\
\text { (ft/sec) }\end{array}$ & $\begin{array}{l}\text { Reynolds } \\
(\operatorname{Re})\end{array}$ & $\begin{array}{l}E / D \\
(i n / i n) \\
\star \star\end{array}$ & $f_{* \star *}$ & $\begin{array}{l}\mathrm{H}_{L} \\
(\mathrm{ft}) \\
\star * * *\end{array}$ & $\begin{array}{l}\text { Le } \\
(f t)\end{array}$ \\
\hline 2.4 & $1: 16$ & 2455 & 0.00023 & 0.048 & 3.55 & 90.7 \\
\hline 3.4 & $1 ! 434$ & 3034 & 0.00023 & 0.044 & 5.86 & 106.7 \\
\hline 5.4 & 2.122 & 4490 & 0.00023 & 0.038 & 10.49 & 100.6 \\
\hline 8.4 & 2.785 & 5893 & 0.00023 & 0.035 & 17.42 & 105.2 \\
\hline 10.4 & 3.193 & 6756 & 0.00023 & 0.034 & 22.05 & 103.2 \\
\hline 14.4 & $3: 903$ & 8258 & 0.00023 & 0.032 & 31.3 & 105.2 \\
\hline 20.4 & 4.754 & 10059 & 0.00023 & 0.03 & 45.18 & 109.2 \\
\hline 25.4 & 5.358 & 11338 & 0.00023 & 0.0296 & 56.75 & 109.4 \\
\hline 29.4 & 5.827 & 12330 & 0.00023 & 0.029 & 66.0 & 109.8 \\
\hline
\end{tabular}

* Pressure from Figure 2 .

** $E=0.00007$ inch (CRANE Technical Paper 410 and Du Pont Std DG $2.3 \mathrm{~B}$, Table 1$), E / D=$ relative roughness, $D=$ tubing $I . D$. (inch).

*** f - friction factor from MOODY diagram.

**** $(2.313 \times$ Pressure $)-2$, see $2^{\prime}$ dimension Figure 1 


\section{TABLE 3}

(For Water Flow in 1/4-inch O.D., 0.180-inch I.D. Tubing)

\begin{tabular}{|c|c|c|c|c|c|c|}
\hline $\begin{array}{c}\text { Pressure } \\
\left(\text { Lbs } / \text { in }^{2}\right) \\
\star\end{array}$ & $\begin{array}{l}\text { Velocicy } \\
(\mathrm{ft} / \mathrm{sec})\end{array}$ & $\begin{array}{l}\text { Reynolds } \\
(\operatorname{Re})\end{array}$ & $\begin{array}{c}E / D \\
(i n / i n) \\
\star \star\end{array}$ & $E_{* \star *}$ & $\begin{array}{l}\mathrm{H}_{\mathrm{L}} \\
(\mathrm{ft}) \\
\star * * *\end{array}$ & $\begin{array}{l}\text { Le } \\
\text { (ft) }\end{array}$ \\
\hline 3.4 & 1.462 & 2257 & 0.00054 & 0.048 & 5.9 & 55.5 \\
\hline 8.4 & 2.304 & 3557 & 0.00054 & 0.041 & 17.46 & 77.49 \\
\hline 14.4 & 3.191 & 4927 & 0.00054 & 0.037 & 31.34 & 80.35 \\
\hline 21.4 & 4.008 & 6188 & 0.00054 & 0.0345 & 47.53 & 82.84 \\
\hline 29.4 & 4.765 & 7357 & 0.00054 & 0.033 & 66.04 & 85.13 \\
\hline
\end{tabular}

* Pressure from Figure 2.

*t $E=0.00007$ inch (CRANE Technical Paper 410 and Du Pont std DG $2.3 \mathrm{~B}$ Table 1$), E / D=$ relative roughness, $D=$ eubing I.D. (inch).

*** $f$ - friction factor from MOODY diagram.

**** (2.313 x Pressure) - 2, see 2' dimension Figure 1: 
TABLE 4

\begin{tabular}{|c|c|c|c|c|c|c|c|}
\hline Slurry Batch & $\begin{array}{l}\text { Frit, type } \\
\text { and size }\end{array}$ & $\begin{array}{l}\text { Yield Stress, } \\
\tau_{\text {, dynes } / \mathrm{cm}^{2}}\end{array}$ & $\frac{\text { Rheology* }}{\text { Consistency }}$ & $\begin{array}{l}\text { Wt. \% } \\
\text { Solids }\end{array}$ & $\begin{array}{l}\text { Flow Tube } \\
\text { Size, inch }\end{array}$ & $\begin{array}{l}\text { Pressure } \\
\text { Drop, psi. } \\
\text { at } 0.5 \mathrm{gpm}\end{array}$ & $\begin{array}{l}\text { Pressure to } \\
\text { Initiate Flow, } \\
+2 \text { psi. }\end{array}$ \\
\hline $\begin{array}{l}\text { No. Formic } \\
\text { Ac id Treated }\end{array}$ & $\begin{array}{l}131 \text { Frit, }-80 \\
\text { Mesh }\end{array}$ & 100 & 20 & 40 & $\begin{array}{l}1 / 2 \\
3 / 8 \\
1 / 4 \\
\end{array}$ & $\begin{array}{r}16 \\
33 \\
- \\
\end{array}$ & $\begin{array}{l}13 \\
16 \\
21 \\
\end{array}$ \\
\hline $\begin{array}{l}\text { No. } 2 \\
\text { Untreated }\end{array}$ & $\begin{array}{l}131 \text { Frit, }-80 \\
\text { Mesh }\end{array}$ & 190 & 35 & 40 & $\begin{array}{l}1 / 2 \\
3 / 8 \\
1 / 4 \\
\end{array}$ & $\begin{array}{l}19 \\
36 \\
- \\
\end{array}$ & $\begin{array}{l}10 \\
16 \\
25\end{array}$ \\
\hline $\begin{array}{l}\text { No. } 3 \\
\text { Untreated }\end{array}$ & $\begin{array}{l}131 \text { Frit, } 50 \% \\
-100,50 \%-50 \\
+100 \text { Mesh }\end{array}$ & 170 & 20 & 41 & $\begin{array}{l}1 / 2 \\
3 / 8 \\
1 / 4 \\
\end{array}$ & $\begin{array}{l}22 \\
35 \\
- \\
\end{array}$ & $\begin{array}{l}15 \\
20 \\
30\end{array}$ \\
\hline $\begin{array}{l}\text { No. } 4 \\
\text { Untreated }\end{array}$ & $\begin{array}{l}131 \text { Erit, } 50 \% \\
-100,50 \%-50 \\
+100, \text { Mesh } \\
\end{array}$ & 135 & 25 & 48 & $\begin{array}{l}1 / 2 \\
3 / 8 \\
1 / 4 \\
\end{array}$ & $\begin{array}{l}24 \\
49 \\
- \\
\end{array}$ & $\begin{array}{l}13 \\
19 \\
33 \\
\end{array}$ \\
\hline $\begin{array}{l}\text { No. } 5 \\
\text { Untreated }\end{array}$ & $\begin{array}{l}140 \text { Frit, } \\
-200 \text { Mesh }\end{array}$ & 58 & 8 & 39 & $\begin{array}{l}1 / 2 \\
3 / 8 \\
1 / 4 \\
\end{array}$ & $\begin{array}{l}10 \\
31 \\
- \\
\end{array}$ & $\begin{array}{l}7 \\
10 \\
- \\
\end{array}$ \\
\hline $\begin{array}{l}\text { No. } 6 \\
\text { Unireated }\end{array}$ & $\begin{array}{l}140 \text { Frit, } \\
-200 \text { Mesh }\end{array}$ & 511 & 49 & 47 & $\begin{array}{l}1 / 2 \\
3 / 8 \\
1 / 4 \\
\end{array}$ & $\begin{array}{l}45 \\
- \\
- \\
\end{array}$ & $\begin{array}{l}10 \\
- \\
- \\
\end{array}$ \\
\hline
\end{tabular}

* Values shown are averages of several determinations rounded to nearest whole numbers. 
TABLE 5

\section{Slurry Rheology Data}

\begin{tabular}{|c|c|c|c|c|c|c|c|c|}
\hline \multirow[b]{3}{*}{$\begin{array}{l}\text { Number of } \\
\text { Samples }\end{array}$} & \multicolumn{4}{|c|}{ FORMIC ACID TREATED SIURRY } & \multicolumn{4}{|c|}{ UNTREATED SLURRY } \\
\hline & $\begin{array}{l}\text { Yield stress, } \\
\tau_{y} \text { dynes } / \mathrm{cm}^{2}\end{array}$ & $\begin{array}{l}\text { Consistency, } \\
\eta \text {, cent ipoise }\end{array}$ & $\begin{array}{l}\text { Density, } \\
\text { gms/cc }\end{array}$ & $\begin{array}{l}\text { We. \% } \\
\text { Solids }\end{array}$ & $\begin{array}{l}\text { Yield Stress, } \\
\tau_{y,} \text { dynes } / \mathrm{cm}^{2}\end{array}$ & $\begin{array}{l}\text { Consistency, } \\
\eta \text {. centipoise }\end{array}$ & $\begin{array}{r}\text { Density, } \\
, \mathrm{gms} / \mathrm{cc} \\
\end{array}$ & $\begin{array}{l}\text { Wt. } \% \\
\text { Sol ids } \\
\end{array}$ \\
\hline & 6 & 6 & 6 & 6 & 7 & 4 & 6 & 7 \\
\hline Mean, $\vec{x}$ & 104.16 & 22.14 & 1.36 & 39.7 & 191.57 & 34.87 & 1.49 & 40.64 \\
\hline $\begin{array}{l}\text { Std. } \\
\text { Deviation, }\end{array}$ & 17.4 & 5.8 & 0.046 & 0.26 & 74.4 & 6.1 & 0.079 & 0.27 \\
\hline \multirow[t]{2}{*}{ Variance, } & 303.4 & 33.88 & 0.002 & 0.068 & 5541 & 36.5 & 0.0062 & 0.073 \\
\hline & \multicolumn{4}{|c|}{$\begin{array}{l}\text { Laboratory Sample Identification } \\
\qquad 82-176,177,181,183,186,187\end{array}$} & \multicolumn{4}{|c|}{$\begin{array}{l}\text { Laboratory Sample Identification } \\
\qquad 82-168,169,174,175,201,205,206\end{array}$} \\
\hline
\end{tabular}




\section{Appendix A}

\section{Typical Feed Compositions}

\section{Frit}

Type 131

\begin{tabular}{lrl} 
Component & & $\mathrm{Wt} \%$ \\
\cline { 1 - 1 } $\mathrm{SiO}_{2}$ & & 57.9 \\
$\mathrm{~B}_{2} \mathrm{O}_{3}$ & & 14.7 \\
$\mathrm{Na}_{2} \mathrm{O}$ & & 17.7 \\
$\mathrm{Li}_{2} \mathrm{O}$ & 5.7 \\
$\mathrm{MgO}$ & 2.0 \\
$\mathrm{TiO}_{2}$ & 1.0 \\
$\mathrm{La}_{2} \mathrm{O}_{3}$ & .5 \\
$\mathrm{ZrO}_{2}$ & .5
\end{tabular}

Type 140

\begin{tabular}{|c|c|}
\hline Componer & Wt\% \\
\hline $\mathrm{SiO}_{2}$ & 60.20 \\
\hline $\mathrm{B}_{2} \mathrm{O}_{3}$ & 16.20 \\
\hline $\mathrm{Na}_{2} \mathrm{O}$ & 13.90 \\
\hline $\mathrm{Li}_{2} \mathrm{O}$ & 4.70 \\
\hline $\mathrm{MgO}$ & 1.63 \\
\hline $\mathrm{Al}_{2} \mathrm{O}_{2}$ & 0.63 \\
\hline $\mathrm{CaO}$ & 1.10 \\
\hline $\mathrm{TiO}_{2}$ & 0.06 \\
\hline $\mathrm{H}_{2} \mathrm{O}$ & 0.14 \\
\hline $\mathrm{ZnO}$ & 0.34 \\
\hline $\mathrm{BaO}$ & 0.40 \\
\hline
\end{tabular}

Sludge

\begin{tabular}{lcc}
$\begin{array}{l}\text { Unformated } \\
\text { Component }\end{array}$ & & Wt\% \\
\cline { 1 - 1 } $\mathrm{Fe}_{2} \mathrm{O}_{3}$ & & 45.5 \\
$\mathrm{Al}_{2} \mathrm{O}_{3}$ & & 16.8 \\
$\mathrm{MnO}$ & & 12.5 \\
$\mathrm{CaO}$ & & 5.4 \\
Zeolite & & 7.4 \\
$\mathrm{NiO}$ & & 3.8 \\
$\mathrm{CsOH}$ & & .06 \\
$\mathrm{SiO}_{2}$ & 7.2 \\
$\mathrm{Na}_{2} \mathrm{CO}_{3}$ & .9 \\
$\mathrm{Na}_{2} \mathrm{SO}_{4}$ & .4
\end{tabular}

\begin{tabular}{lll}
$\begin{array}{l}\text { Formated } \\
\text { Component }\end{array}$ & & Wt\% \\
\cline { 1 - 1 } \cline { 1 - 1 } $\mathrm{Fe}(\mathrm{OH})_{3}$ & & 41.2 \\
$\mathrm{Al}(\mathrm{OH})_{3}$ & & 17.3 \\
$\mathrm{Mn}(\mathrm{COOH})_{2}$ & & 14.3 \\
$\mathrm{Ca}(\mathrm{COOH})_{2}$ & & 8.5 \\
$\mathrm{ZeO} 1 \mathrm{ice}$ & & 5.1 \\
$\mathrm{Ni}(\mathrm{COOH})_{2}$ & & 4.3 \\
$\mathrm{CsOH}$ & & 0.06 \\
$\mathrm{SiO}_{2}$ & & 7.9 \\
$\mathrm{Na}_{2} \mathrm{CO}_{3}$ & 1.0 \\
$\mathrm{Na}_{2} \mathrm{SO}_{4}$ & 0.4
\end{tabular}

